\title{
THE POTENTIAL OF EXOSOMES FOR THE DIAGNOSIS AND TREATMENT OF DUCHENNE MUSCULAR DYSTROPHY
}

\author{
Galkin $\|^{1,2}$, Egorova TV1,3凶
}

${ }^{1}$ Marlin Biotech LLC, Moscow, Russia

${ }^{2}$ A. N. Belozersky Institute of Physico-Chemical Biology, Moscow, Russia

${ }^{3}$ Institute of Gene Biology, Russian Academy of Sciences, Moscow, Russia

Duchenne muscular dystrophy is the most common type of muscular dystrophy. There is no effective cure for this disease. Recently, researchers have started to look at the therapeutic potential of exosomes - small (40-100 nm) vesicles secreted by cells into the extracellular environment. They transport a few types of macromolecules, including microRNA and proteins, that can be analyzed to estimate the efficacy of the applied therapy. Besides, exosomes can be harnessed for delivering therapeutic components (microRNA, antisense oligonucleotides) to the target tissue. Below, we analyze the available literature and assess the feasibility of using exosomes in the diagnosis and treatment of Duchenne muscular dystrophy. We conclude that exosomes can have their place in the arsenal of researchers and clinicians once some technical issues are solved.

Keywords: Duchenne muscular dystrophy, exosomes, targeted drug delivery, liquid biopsy, gene therapy

Author contribution: Galkin II, Egorova TV — literature analysis and manuscript preparation.

$\triangle$ Correspondence should be addressed: Tatiana V. Egorova

Vavilova 34/5, Moscow, 119334; t.dimitrieva@marlinbiotech.com

Received: 21.07.2019 Accepted: 05.08.2019 Published online: 12.08.2019

DOI: 10.24075/brsmu.2019.049

\section{ВОЗМОЖНОСТИ ПРИМЕНЕНИЯ ЭКЗОСОМ ДЛЯ ДИАГНОСТИКИ И ЛЕЧЕНИЯ МИОДИСТРОФИИ ДЮШЕННА}

\author{
И. И. Галкин ${ }^{1,2}$, Т. В. Егорова ${ }^{1,3} \bowtie$ \\ ${ }^{1}$ ООО «Марлин Биотех», Москва, Россия \\ ${ }^{2}$ Институт физико-химической биологии имени А. Н. Белозерского, Москва, Россия \\ ${ }^{3}$ Институт биологии гена, Москва, Россия
}

\begin{abstract}
Миодистрофия Дюшенна - наиболее часто встречающаяся форма миодистрофии. Однако эффективного лечения этого заболевания до сих пор не разработано. В настоящее время появляются работы, посвященные использованию экзосом в моделях миодистрофии Дюшенна. Экзосомы, небольшие (40-100 нм) везикулы, секретируемые клетками в межклеточное пространство, переносят некоторые макромолекулы (микроРНК, белки), анализ которых может быть использован для неинвазивной оценки успешности применяемой терапии. Кроме того, они могут обеспечивать адресную доставку активных веществ (например, микроРНК, антисмысловых олигонуклеотидов). Анализируя имеющиеся данные и оценивая возможность диагностики и терапии дистросии Дюшенна с помощью этих везикул, мы предполагаем, что экзосомы могут занять место в арсенале исследователей и врачей, если удастся решить некоторые технические проблемы.
\end{abstract}

Ключевые слова: миодистрофия Дюшенна, экзосомы, адресная доставка, жидкостная биопсия, генетическая терапия

Информация о вкладе авторов: И. И. Галкин, Т. В. Егорова - анализ литературы, написание текста статьи.

$凶$ Для корреспонденции: Татьяна Владимировна Егорова

ул. Вавилова, 34/5, г. Москва, 119334; t.dimitrieva@marlinbiotech.com

Статья получена: 21.07.2019 Статья принята к печати: 05.08.2019 Опубликована онлайн: 12.08.2019

DOI: $10.24075 /$ vrgmu.2019.049

Duchenne muscular dystrophy (DMD) is an X-linked recessive disorder caused by mutations in the DMD gene resulting in the deficient or dysfunctional protein known as dystrophin. The disease is characterized by progressive muscle degeneration and fibrosis. Patients lose ambulation at the age of 8 to 12 years and die in their 20s, usually from cardiac or respiratory failure. Those with partially functional dystrophin develop a milder form of the disease called Becker muscular dystrophy.

The majority of currently existing strategies for managing DMD only seek to alleviate its symptoms and include physical therapy and exercise, minor orthotic interventions aimed at preventing contracture, assisted ventilation, and glucocorticoids [1]. These treatments give the affected patients the chance to walk and move independently for longer and increase their life expectancy to 30 years. Obviously, they cannot eliminate the cause of the disease, unlike gene therapies, which can restore dystrophin expression and function. Gene therapies for DMD range from adeno-associated viral vectors (AAV) for the delivery of microdystrophin (a truncated but functional version of the protein) to the muscle [2], to exon skipping (pre-messenger RNA splicing mediated by modified oligonucleotides or CRISPR/Cas systems) [3]. Each of the listed approaches has its own limitations and downsides. AAV-based dystrophin delivery can provoke an unwanted immune response to capsid proteins. Besides, due to the small packaging capacity, the vector can only carry a shortened version of dystrophin inferior to the full-length protein in terms of its function. The efficacy of exon skipping is low. It targets a narrow range of mutations and, therefore, can be beneficial for a small subpopulation of patients [3]. Challenges associated with drug delivery to muscles are the primary hurdle affecting the efficacy of both conventional and innovative DMD treatments. This spurs the development of novel approaches. Recently, exosomes have been receiving increasing attention as promising drug delivery systems [4].

Exosomes are the smallest extracellular vesicles secreted by cells into the extracellular environment, such as blood, lymph, growth media, etc. They are usually reported to be 
40 to $100 \mathrm{~nm}$ in size; larger exosomes sized up to $150 \mathrm{~nm}$ are rarely reported. Unlike other extracellular vesicles, such as apoptotic bodies (50 to $1,000 \mathrm{~nm}$ in diameter) or microvesicles (100 to $300 \mathrm{~nm}$ in diameter) "blebbed" from the cell membrane, exosomes are secreted after a multivesicular body has fused with the membrane [5]. Initially, exosomes were thought to be "trash bags" responsible for disposing of cellular waste. Later, they were shown to mediate intercellular communication by transporting proteins, RNA and other molecules [5]. On their lipid membrane, exosomes carry a number of surface proteins, including CD9, CD63 and some others, as well as the components of the major histocompatibility complex. On the one hand, these surface proteins prevent exosomes from being eliminated from the bloodstream; on the other hand, they stimulate receptor-mediated endocytosis [6, 7]. One way of modifying exosome surface proteins is click chemistry. Alternatively, cell cultures can be engineered expressing an exosomal surface protein that contains a guide peptide sequence. The guide peptide on the surface of exosomes enhances their affinity for the receptors found on the target cells $[6,8]$. Similarly, exosomes can be loaded with useful cargoes - biological macromolecules (nucleic acids, proteins) and low molecular weight compounds (inhibitors and antisense oligonucleotides, ASO) [6]. Compared to liposomes, exosomes seem to be much more effective and appealing candidates for drug delivery because they can be directed precisely into the target tissue once their surface has been modified; they also demonstrate low immunogenicity and high loading potential. There have been attempts to use exosomes for therapeutic applications [9], but generally such therapies are still in development. Most often, exosomes are employed as effective diagnostic markers of cancer, cardiovascular and neurological diseases [9].

\section{Exosomes for Duchenne muscular dystrophy: diagnostics}

The diagnosis of Duchenne/Becker muscular dystrophy is based on the results of molecular and genetic tests (PCR, MLPA, sequencing) that can accurately localize and identify the causative mutation. Muscle biopsies are performed in difficult cases to estimate the amount of dystrophin, its distribution in the muscle tissue and the overall condition of muscle fibers. Importantly, patients with DMD should be monitored throughout treatment. However, frequent biopsies are poorly tolerated by patients and provide information about a small area of the affected muscle. A 6-minute walk test is relevant for outpatients only, and its result is largely determined by the ability of a patient to concentrate and their willingness to follow the instructions. This necessitates development of minimally invasive and reliable methods for the assessment of a patient's condition during and after therapy. The solution might be provided by a type of so-called "liquid biopsy": the analysis of microRNA contained in exosomes isolated from a patient's blood. So far, several microRNAs have been explored, including miR-1, miR21, miR-29, miR-31, miR-29, miR-133, miR-133b, and miR206 , that participate in muscle tissue repair and differentiation. Three main muscle-associated microRNAs (miR-1, miR-133 and miR-206) are elevated in the blood serum of patients with DMD; interestingly, miR-206 levels are increased even in the female carriers of the defective gene [10]. Some authors point to another large group of microRNAs (miR-22, miR-30, miR95, miR-181, miR-193b, miR-208a, miR-208b, miR-378, and miR-499) that could serve as a DMD marker; however, these data need further confirmation. Still, the dynamics of exosomal muscle-associated microRNA in the course of treatment with such drugs as Eteplirsen (a phosphorodiamidate morpholino oligomer from the class of synthetic ASO used for exon skipping [3]) can provide valuable information about the efficacy of the applied therapy [10].

\section{Exosomes for Duchenne muscular dystrophy: therapy based on native exosomes}

Attempts to harness stem cells for therapeutic applications date quite far back. Stem cells tested in DMD models are cardiac progenitor ("cardiosphere-derived") cells [11]. The clinical trials of the drug based on such cells is now in Phase II. The therapeutic effect of stem cells is linked to their ability to stimulate tissue differentiation and regeneration. Recent studies demonstrated that exosomes shed by stem cells mediate signal transfer from stem cells to the target tissue. A study conducted in mdx mice revealed that intracardiac [11] and intravenous [12] administration of exosomes derived from cardiospheres reproduced almost all beneficial effects of exosomes naturally delivered by stem cells. Interestingly, dystrophin was detected in the muscle tissue following the administration of cardiospherederived exosomes, but no dystrophin or its mRNA were found inside the exosomes. The analysis of RNA contained in the exosomes revealed that the latter were enriched in miR-148a. Intramuscular injections of miR-148a led to a partial restoration of dystrophin levels, suggesting a possible mechanism of action for cardiosphere-derived exosomes [11]. Similarly, exosomes originating from other sources, such as $\mathrm{C} 2 \mathrm{C} 12[13,14]$ and placental [15] cells, stimulated muscle regeneration, reduced fibrosis and improved the functional state of the muscle. The beneficial effect of exosomes derived from placental cells was determined by microRNA (miR-29). That said, it should be noted that little attention has been paid to the possible treatment-related adverse events. Most often, the side effects of therapeutic exosomes on experimental animals are estimated by measuring animal weight, levels of hepatic enzymes and blood urea; the immune response remains overlooked.

\section{Exosomes for Duchenne muscular dystrophy: exosomes loaded with therapeutic agents. Targeted delivery}

Although native exosomes hold promise for DMD treatment, they do not solve the key problem of dystrophin deficiency, similar to existing approaches. Using exosomes as drug delivery platforms may offer the long-awaited solution. The idea of delivering full-length dystrophin, its truncated version (microdystrophin) or the gene itself to the target tissue looks appealing. However, the full-length dystrophin molecule is 150$180 \mathrm{~nm}$ in size, which exceeds the maximum possible diameter of an exosome. This means that attempts to load the protein or its coding sequence onto an exosome may fail. However, exosomes can be employed for delivering low molecular weight compounds. Some of DMD treatment options rely on the use of synthetic ASO. In one of the studies, a peptide capable of binding selectively to the exosomal surface protein CD63 was conjugated to ASO. The resulting compound enabled more effective exon skipping, as compared to the unconjugated antisense nucleotide. Moreover, when bound to the M12 muscle-specific peptide, the above-mentioned peptide facilitated targeted delivery of exosomes into the muscle tissue [6]. In another study, exosomes were derived from transfected cells that expressed the chimeric protein Lamp2b (the lysosomal protein appearing also on the surface of exosomes) fused with muscle- or neuron-specific peptides. The modified exosomes 
succesfuly delivered effector molecules (short interfering RNA) into the target cells and tissues [8].

\section{CONCLUSIONS}

In spite of extensive effort, there is no effective treatment for Duchenne muscular dystrophy. Existing therapies are symptomatic and have serious limitations. Exosomes boast low immunogenicity; in addition, their surface can be modified. Therefore, these vesicles are promising candidates for drug delivery. The analysis of a patient's exosomes can facilitate the diagnosis and help to monitor the response to treatment. However, isolation, standardization and loading of exosomes require further refinement and optimization. Also, the immunogenic properties of exosomes are still understudied. Combining the use of exosomes for muscle regeneration with ASO loading and modification of exosomal surface proteins with muscle-specific peptides looks like a promising approach.

\section{References}

1. Birnkrant DJ, Bushby K, Bann CM, Apkon SD, Blackwell A, Brumbaugh D, et al. Diagnosis and management of Duchenne muscular dystrophy, part 1: diagnosis, and neuromuscular, rehabilitation, endocrine, and gastrointestinal and nutritional management. Lancet Neurol. 2018; 17 (3): 251-67. DOl: 10.1016/S1474-4422(18)30024-3. PubMed PMID: 29395989; PMCID: PMC5869704.

2. Duan D. Systemic AAV Micro-dystrophin Gene Therapy for Duchenne Muscular Dystrophy. Mol Ther. 2018; 26 (10): 2337-56. DOI: 10.1016/j.ymthe.2018.07.011. PubMed PMID: 30093306; PMCID: PMC6171037.

3. Lim KR, Maruyama R, Yokota T. Eteplirsen in the treatment of Duchenne muscular dystrophy. Drug Des Devel Ther. 2017; (11): 533-45. DOI: 10.2147/DDDT.S97635. PubMed PMID: 28280301; PMCID: PMC5338848.

4. Bunggulawa EJ, Wang W, Yin T, Wang N, Durkan C, Wang Y, et al. Recent advancements in the use of exosomes as drug delivery systems. J Nanobiotechnology. 2018; 16 (1): 81. DOI: 10.1186/ s12951-018-0403-9. PubMed PMID: 30326899; PMCID: PMC6190562.

5. Raposo G, Stoorvogel W. Extracellular vesicles: exosomes, microvesicles, and friends. The Journal of cell biology. 2013; 200 (4): 373-83. DOI: 10.1083/jcb.201211138. PubMed PMID: 23420871; PMCID: PMC3575529.

6. Gao X, Ran N, Dong X, Zuo B, Yang R, Zhou Q, Moulton HM, Seow $Y$, Yin $H$. Anchor peptide captures, targets, and loads exosomes of diverse origins for diagnostics and therapy. Sci Transl Med. 2018; 10 (444). DOI: 10.1126/scitranslmed.aat0195 PubMed PMID: 29875202.

7. Kamerkar S, LeBleu VS, Sugimoto H, Yang S, Ruivo CF, Melo SA, et al. Exosomes facilitate therapeutic targeting of oncogenic KRAS in pancreatic cancer. Nature. 2017; 546 (7659): 498-503. DOI: 10.1038/nature22341. PubMed PMID: 28607485; PMCID: PMC5538883.

8. Alvarez-Erviti L, Seow Y, Yin H, Betts C, Lakhal S, Wood MJ. Delivery of siRNA to the mouse brain by systemic injection of targeted exosomes. Nat Biotechnol. 2011; 29 (4): 341-5. DOl:

\section{Литература}

1. Birnkrant DJ, Bushby $\mathrm{K}$, Bann CM, Apkon SD, Blackwell A, Brumbaugh D, et al. Diagnosis and management of Duchenne muscular dystrophy, part 1: diagnosis, and neuromuscular, rehabilitation, endocrine, and gastrointestinal and nutritional management. Lancet Neurol. 2018; 17 (3): 251-67. DOl: 10.1016/S1474-4422(18)30024-3. PubMed PMID: 29395989; PMCID: PMC5869704.

2. Duan D. Systemic AAV Micro-dystrophin Gene Therapy for Duchenne Muscular Dystrophy. Mol Ther. 2018; 26 (10): 2337-56. DOI: 10.1016/j.ymthe.2018.07.011. PubMed PMID: 30093306; PMCID: PMC6171037.

3. Lim KR, Maruyama R, Yokota T. Eteplirsen in the treatment of Duchenne muscular dystrophy. Drug Des Devel Ther. 2017; (11): 533-45. DOI: 10.2147/DDDT.S97635. PubMed PMID: 28280301 ; PMCID: PMC5338848.

4. Bunggulawa EJ, Wang W, Yin T, Wang N, Durkan C, Wang Y, et al. Recent advancements in the use of exosomes as drug delivery systems. J Nanobiotechnology. 2018; 16 (1): 81. DOI: 10.1186/ s12951-018-0403-9. PubMed PMID: 30326899; PMCID: PMC6190562.

5. Raposo G, Stoorvogel W. Extracellular vesicles: exosomes, microvesicles, and friends. The Journal of cell biology. 2013; 200 (4): 373-83. DOI: 10.1083/jcb.201211138. PubMed PMID: 23420871; PMCID: PMC3575529

6. Gao X, Ran N, Dong X, Zuo B, Yang R, Zhou Q, Moulton HM, Seow $Y$, Yin H. Anchor peptide captures, targets, and loads exosomes of diverse origins for diagnostics and therapy. Sci Transl Med. 2018; 10 (444). DOI: 10.1126/scitranslmed.aat0195. PubMed PMID: 29875202

7. Kamerkar S, LeBleu VS, Sugimoto H, Yang S, Ruivo CF, Melo SA, 
et al. Exosomes facilitate therapeutic targeting of oncogenic KRAS in pancreatic cancer. Nature. 2017; 546 (7659): 498-503. DOI: 10.1038/nature22341. PubMed PMID: 28607485; PMCID: PMC5538883.

8. Alvarez-Erviti L, Seow Y, Yin H, Betts C, Lakhal S, Wood MJ. Delivery of siRNA to the mouse brain by systemic injection of targeted exosomes. Nat Biotechnol. 2011; 29 (4): 341-5. DOl: 10.1038/nbt.1807. PubMed PMID: 21423189.

9. Kim YS, Ahn JS, Kim S, Kim HJ, Kim SH, Kang JS. The potential theragnostic (diagnostic + therapeutic) application of exosomes in diverse biomedical fields. Korean J Physiol Pharmacol. 2018; 22 (2): 113-25. DOI: 10.4196/kjpp.2018.22.2.113. PubMed PMID: 29520164; PMCID: PMC5840070.

10. Coenen-Stass AML, Wood MJA, Roberts TC. Biomarker Potential of Extracellular miRNAs in Duchenne Muscular Dystrophy. Trends Mol Med. 2017; 23 (11): 989-1001. DOI: 10.1016/j. molmed.2017.09.002. PubMed PMID: 28988850.

11. Aminzadeh MA, Rogers RG, Fournier M, Tobin RE, Guan $X$, Childers MK, et al. Exosome-Mediated Benefits of Cell Therapy in Mouse and Human Models of Duchenne Muscular Dystrophy. Stem Cell Reports. 2018; 10 (3): 942-55. DOI: 10.1016/j. stemcr.2018.01.023. PubMed PMID: 29478899; PMCID: PMC5918344.
12. Rogers RG, Fournier M, Sanchez L, Ibrahim AG, Aminzadeh MA, Lewis Ml, et al. Disease-modifying bioactivity of intravenous cardiosphere-derived cells and exosomes in mdx mice. $\mathrm{JCl}$ Insight. 2019; 4 (7). DOI: 10.1172/jci.insight.125754. PubMed PMID: 30944252; PMCID: PMC6483717.

13. Su X, Shen $Y$, Jin $Y$, Jiang M, Weintraub N, Tang Y. Purification and Transplantation of Myogenic Progenitor Cell Derived Exosomes to Improve Cardiac Function in Duchenne Muscular Dystrophic Mice. J Vis Exp. 2019; (146). DOI: 10.3791/59320. PubMed PMID: 31033952

14. Su X, Jin Y, Shen Y, Ju C, Cai J, Liu Y, et al. Exosome-Derived Dystrophin from Allograft Myogenic Progenitors Improves Cardiac Function in Duchenne Muscular Dystrophic Mice. J Cardiovasc Transl Res. 2018; 11 (5): 412-9. DOI: 10.1007/s12265-0189826-9. PubMed PMID: 30155598; PMCID: PMC6212302.

15. Bier A, Berenstein P, Kronfeld N, Morgoulis D, Ziv-Av A, Goldstein H, et al. Placenta-derived mesenchymal stromal cells and their exosomes exert therapeutic effects in Duchenne muscular dystrophy. Biomaterials. 2018; (174): 67-78. DOI: 10.1016/j. biomaterials.2018.04.055. PubMed PMID: 29783118. 